\title{
The Usage Specification OF Registers in Social Media INSTAGRAM
}

\author{
Sang Ayu Isnu Maharani, I Wayan Mulyawan \\ English Department, Udayana University \\ isnu_maharani@unud.ac.id, moelya01@gmail.com
}

\begin{abstract}
This research concerns with the usage specification of registers in social media as a renewable way of communication in the millennial era. The aims of this research were identifying and mapping the usage specification of registers in social media Instagram. It also aimed at finding find out the function of the usage specification of the registers. This research was a combination of qualitative and quantitative research. The method applied for this research was observation method with note-taking techniques. The method used to analyze the data was discourse analysis method. To answer the problems formulated in this research, of Halliday's (1994) register theory was applied.
\end{abstract}

Keywords: usage specification, register, social media, Instagram

\section{INTRODUCTION}

Register is a linguistic phenomenon that exists in society. Register is a variation of language that is caused by the existence of the special characteristics of the needs of the user, for example, it can be found in the written language such as: an advertisement, article, pamphlet and social media. Meanwhile, when viewed from spoken language, we can see them in political language, presentation, parody, football commentator's session and other verbal actions which can not be mentioned one by one.

In the development of today's society, we will easily encounter various linguistic phenomena. The phenomena can be seen in social, alay, or slang language. Social language is the simple, informal language we use when talking face to face with family members or friends. It allows us to use slang terms or communicate feelings, needs and wants using symbolic hand gestures. Alay is short for anak layangan, literally meaning "kite kid". Alay is considered as various non-standard style expressions used regional or almost throughout Indonesia. Meanwhile, Slang is a type of language consisting of words and phrases that are regarded as very informal, are more common in speech than writing. It is typically restricted to a particular context or group of people. Those three linguistic phenomena mentioned are different from register due to the reason that the register is semantic concept that relates with arrangements and context. The linguistic phenomenon that examined in this is research was the usage specification of register in social media Instagram.

As we aware, social media is a contemporary lifestyle that is in high demand and inevitably 'forces' people to be able to understand if they do not want to be considered old-fashioned. Social media gives people the opportunity to become free writers, become independent journalists, become public figures, become online business people, build their self-image and there are many other things that can be done via social media, viewed from positive perspective. Meanwhile, if we look at it from the negative side, it will be easier to find fraud or criminal acts such as human trafficking. Positive and negative things, of course, are always like two sides of coin. We realize, social media has slowly changed the mentality, attitude, lifestyle and also the language of the people.

Language or style/variety of languages conveyed by the public through social media is a form of renewable communication. There is still not much research viewed from the linguistic aspects. Besides, language is also used to carry out integration, social adaptation, tools to express self-expression and also social control. Language variations (registers) found on social media are interesting things to study because there is still limited study or research concerns with this topic. Isnu Maharani \& Mulyawan (2019) studied English registers in social media Instagram. They have explored and focused the research in identifying the English Registers. In the following year (2020) Isnu Maharani \& Mulya wan proceed further research on the usage specification of registers in social media Instagram. The identification and finding of this research is expected to be able to provide additional insight to the academic world about the dynamics of language change that is so rapidly developing in society.

Based on the above introduction, this study seeks to describe the following problems; the usage specification of registers in social media Instagram, and the functions of the usage specification of register in social media Instagram. 
The results of this study are expected to have theoretical and practical benefits. Theoretical benefits aim at broaden the reader's insight, in particular regarding variations in language, register in social media Instagram. In addition, this research is expected to widen "horizon" and perspectives, especially in the field of Sociolinguistics.

\section{MATERIALS AND METHODS}

The data source of this study was registers of eighteen (18) accounts taken from Instagram social media within a period of three months, from January to March 2020. The period of data collection conducted in the 2020 to give updated data for the research. The data was collected based on the frequency of appearance of accounts of particular categories in social media Instagram. The collected data was categorized according to the type of account seen in social media Instagram. The results of the categorization are presented in the form of tables and descriptions.

This study used the observation method and note-taking technique. The collected data taken from posted accounts in Instagram media in the period January-March 2020. The data taken manually by taking screen shot of every collected data. The data taken limited in the period of January-March. Existing data was then categorized based on the usage specifications. The data that has been identified and categorized were then tabulated in tabular form to get the percentage of usage and later described descriptively.

This research applied discourse analysis method. This method was a study that examines or analyzes the language used naturally, either in written or spoken form. The analysis emphasizes the study of language use in social contexts. The discourse in question is the language used to communicate.

The usage specifications of registers found in social media Instagram were grouped and analyzed for the use of the language and also the function of the usage of the registers. The analysis results of the usage specifications were presented in tabular form. The function of the registers was described descriptively.

\section{RESULTS AND DISCUSSION}

\subsection{Result}

This section describes the results of data analysis, namely the usage specification in Social Media, Instagram from January-March 2020 period. The data obtained in the following categories:

(1) Health and Beauty

(2) Minimarkets / supermarkets

(3) Property and Contractors

(4) Restaurant

(5) Services

(6) Convenience stores

\begin{tabular}{|l|l|l|l|}
\hline Category & Account name & Number of Post & Percentage \\
\hline Health and Beauty & Meisa BuluMata & 29 & 0,03 \\
\hline & $\begin{array}{l}\text { Parlour Me Beauty } \\
\text { Salon }\end{array}$ & 59 & 0,07 \\
\hline Mini market/Supermarket & AlfaMart & 88 & 0,11 \\
\hline & Giant Indo & 49 & 0,06 \\
\hline & $\begin{array}{l}\text { Indo Mart } \\
\text { Tip Top Super }\end{array}$ & 29 & 0,13 \\
& Carefour & 104 & 0,03 \\
\hline
\end{tabular}




\begin{tabular}{|l|l|l|l|}
\hline Property and Contractor & Property\&Contractor & 10 & 0,01 \\
\hline Restaurant & Wr.Kayu Manis & 49 & 0,06 \\
& NUI Health Bowls & 41 & 0,05 \\
& Dapoer Sehat & 37 & 0,04 \\
& Cumi Doerr & 10 & 0,01 \\
& Baliku Jamur & 36 & 0,04 \\
\hline Services & Bulu Waxing & 8 & 0,01 \\
& Jualan.Lau & 8 & 0,01 \\
\hline Shops & J.Co Indo Coffee & 21 & 0,02 \\
& Nitra Jaya Kebaya & 100 & 0,12 \\
\hline Total & & 783 & \\
\hline
\end{tabular}

Table 1. Frequency of Accounts Occurrence in Social Media Instagram Period of Jan-March 2020

In category (1), accounts@ Meisa Bulu and @Parlour Me Beauty Salon were found. Meisa Bulu Mata's account consists of 29 data and Parlourme Beauty Salon consists of 59 data. The Minimarket or Supermarket categories, we can get accounts such as@AlfaMart, @Giant Indo, @IndoMart, @ Tip Top Supermarket and @ Transmart Carefour. The frequency of appearance of AlfaMart accounts is 88, Giant Indonesia is 49 data, IndoMart is 105 data. For the Advertising category: Property and Contractor, there are 10 records. The restaurant category contains a total of 173 posts, which in detail are: @Warung Kayu Manis 49 data, 41 data @ NUI Healthy Bowls, @Dapoer Sehat 37 data @ Cumi Doerr there are 10 data, @Baliku Mushroom has 36 data. There are a total of 16 data categories with details found at @Bulu Waxing hut and @ Jualan Lau there are 8 data. The Shops, Barber, Coffee categories are as follows: @ J.Co Indon Coffee Shop has 21 data and the @ Nitra Jaya Kebaya account has 100 data.

\subsection{DISCUSSION}

Ferguson (1971) argues that registers are situations of communication that occur regularly in a society (relating to participants, places, communicative functions, etc.) over time, which tend to develop over time, marking the structure of language and the use of language that is different from the use language in other communication situations.

A communication situation that recurs regularly in a social environment (in terms of participants, settings, communicative functions and so forth) will tend to overtime to develop indentifying markers of language structure and language use, different from the language of other communication situations (Ferguson, 1971).

Register according to Halliday (1994: 54) is a semantic concept that can be defined as an arrangement of meanings that is specifically connected to certain arrangements of terrain, engagement, and means. This arrangement is more familiar with context. Medan refers to what is happening or when the action is taking place, what are actually being said by the parties involved. Involvement refer s to the people who take part in a conversation, the nature of the actors, their position and role. Means refer to the role taken by language in certain situations, such as pointing, explaining, and educating.

Register is a variety of languages based on the user, the language used depends on what is being worked on (Halliday, 1994). 
Registers or variations of language in terms of usage used in certain professions make the language functional. Each register has a specific function. Ferguson (1971) explained that the function of registers or language variations in terms of their use was as follows:

a. Instrumental functions, la nguage oriented to the listener or interlocutor. The la nguage used to regulate the listener's behavior so that the interlocut or wants to obey or follow what is expected by the speaker or writer. This can be doneby using expressions thatexpress demand, appeal or seduction

b. Interaction function, language-oriented contact between parties who are communicating. Register in this case serves to establish and maintain rela tionships and show feelings of friendship or social solidarity. The phra ses used a re usually patterned but like when meeting, getting to know, asking about the situation and so forth.

c. Personality or personal function, language oriented to speakers.

d. Problem-solving function, the language contained in expressions that a sk for, according to or sta te an answer to a problem or problem. The ex pressions used in this function are in the form of questions that require explanation or explanation

e. Imaginary or ima ginary functions, language that is oriented towards the intent that will be conveyed by the speakeror writer

f. Information function, the la nguage used as a tool to provide news or information so that others can know.

From the data category above, we can temporarily see that the Mini market / supermarket account has the highest frequency of appearance, namely the @indomart account with a total of 105 posts, while the lowest frequency is on the services @ jualan.lau account with 8 posts. The lowest category is the services account, each consisting of 8 posts. The usage specification of registers in social media Instagram are as follows, each category is represented by 1 data.

\subsubsection{HEALTH AND BEAUTY CATEGORY}

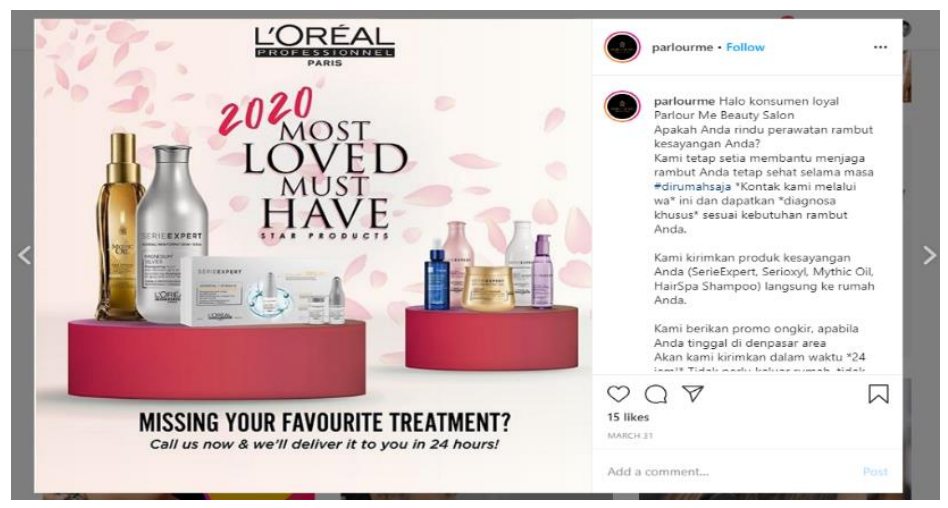

Picture 1. Health and Beauty

From the above data, we can find the use of Indonesian and English. In the visual image display, the dominant color is red as the base for the shampoo, making this image look attractive. The sentences in English are found in:

(a) 2020 Most Loved-Must Have Star Product

(b) Miss your fa vourite Treatment?

(c) Call us now and we'll deliver itu to you in 24 hours

The sentences that appear in Indonesian language are:

(a) Apakah anda rindu perawatan rambut kesayangan anda? (Do you miss yourfavourite hair traitment?)

(b) Kami tetap setia membantu menjaga rambut anda tetap sehat selama masa\#dirumahaja (We are still loyal to a ssist you to keep your hair hea lthy during the period\# \#tayathome

(c) Kontakkami melalui wa inidan dapatkan "diagnose khusus" sesuai kebutuhan rambut anda (Please contactus in this following wa and receive "special diagnose" in accordance to your hair needs)

(d) Kami kirimkan produk kesayangan anda langsung ke rumah anda (We send yourfavourite products directly to your home) 
(e) Kami berikan promo ongkir apabila anda tinggal di Denpasar area (We give promotion of delivery charge if you stay in Denpasar area)

(f) Akan kami kirimkan dalam waktu 24jam (We will send in 24 hours)

From the description of the above sentences, we can see registers or language variations such as:

(a) Callus now

(b) We'll deliver it to you in 24 hours

(c) Kami tetap setia...(We are still loyal.....)

(d) Kontak kami.... (Contact us.............)

(e) Kami berikan promo ongkir....(We give promotion of delivery charge....)

(f) Kami kirimkan dalam waktu 24jam (We send in 24 hours........)

Some of the registers found above are marketing registers that are commonly used to attract customers or buyers by using 2 language versions, Indonesian and English. Parlor me Beauty salon as a women's beauty centre delivers its products through advertising language as listed above. Register repetitions in the presentation of Indonesian and English are found in points (a) and (d), namely call us now and contact us. Other repetitions can also be found in points (b) and (f), namely We will deliver it to you in 24 hours and We send it within 24 hours.

\subsubsection{MINIMARKET/SUPERMARKET CATEGORY}

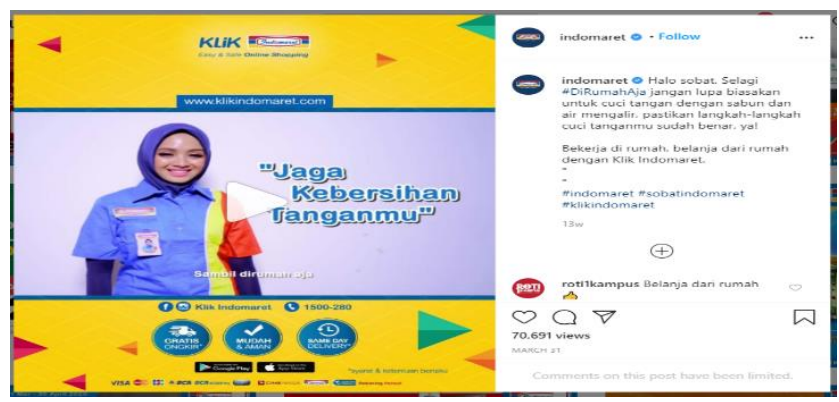

Picture 2. Minimarket/Supermarket

The above category is the mini market category, namely Indomart. The image displayed characterized by IndoMart's costumes and colours. The sentences that appear in the @indomart account are as follows:

Halo sobat

Selagi\#DiRumahAjajangan lupabiasakan untukcucitangan dengan sabun danair mengalir, pa stikan langkah-langkah cuci tanganmu sudahbenar, ya!

Bekerja di rumah, belanja dari rumah, dengan Klik Indomart

Hi friends

While \#stay at home do not forget to getting use to wa sh your hand with soap and running water, ensure your washing hand procedures have done correctly.

Work at home, shop from home, with Indomart click

From the description of above sentence that appears on Instagram, several registers can be found as follows:
(a) Dirumah aja
- just stay at home
(b) Biasakancucitangan - get use to wash your hand
(c) Bekerja dirumah $\quad$ - work at home
(d) Belanja dari rumah - shop from home
(e) Klik Indomart
- Indomart click

The register that appears on this account more emphasis on social appeals or messages to the community. Perhaps this is a form of Indomart's participation and concern toward events that occurred during this pandemic. A register with hashtag \#dirumah aja is one of the viral registers in the 
community. During pandemic, people are limited to leave the house and suggested to do activities from home, one of which is shopping from home, point (d). A new habit that is also one of the registers during the pandemic is Biasakan cuci tangan as seen in point (b). The register that stated in point (e) shows recommendation to conduct virtual activities; online shopping by Indomart click.

\subsubsection{PRoperty and Contractor CATEgory}

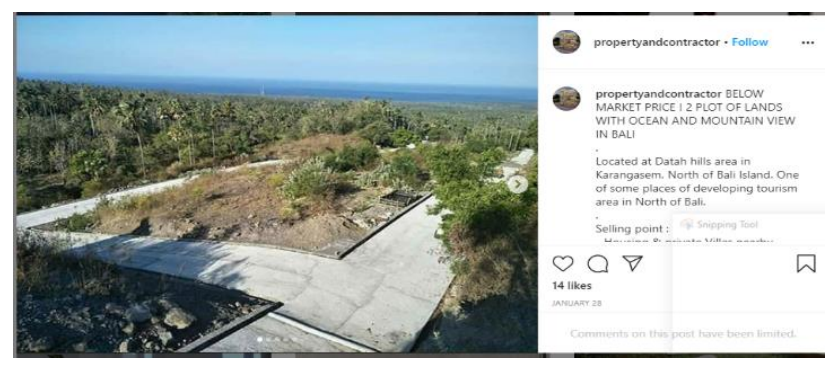

Picture 3. Property and Contractor

The above data shows the application of English language in delivering the information. The sentences are:
(a) Below Market Place
(b) 2 Plots of land with ocean and mountain view in Bali
(c) Loca ted in Da tah hills area in Ka rangasem
(d) One of some pieces of developing tourism area in North of Bali

The above sentences include following registers, they are:

(a) Below Market Place

(b) 2 plots of land

(c) Loca ted in....

(d) One of some pieces....

Registers in English are commonly used as a form of information and product introductions offered by the @ propertyandcontractor account. The register genre in the above account is oriented towards sales and marketing terminology and tends to be aimed at foreigners.

\subsubsection{RESTAURANT CATEGORY}

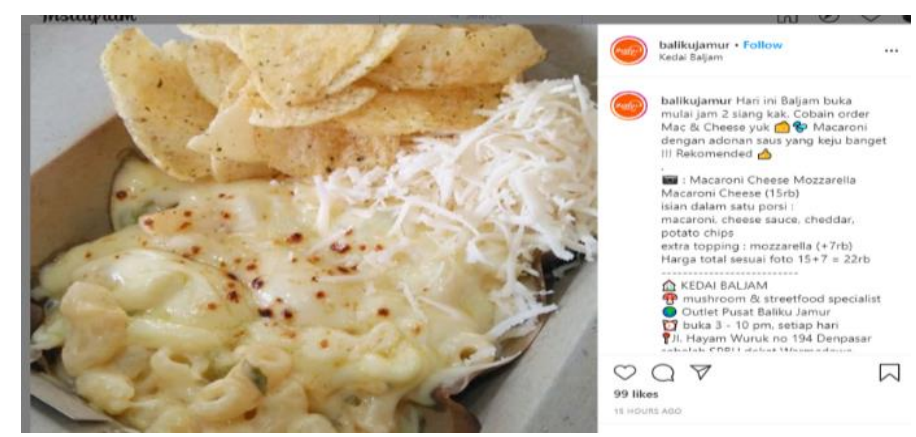

\section{Picture 4. Restaurant}

The image of mushrooms above is a type of information register that provides information about food, namely the @ balikujamur account. The language used is Indonesian. Several registers were found from this account:
(a) Hari ini baljam buka mulai jam 2 siang - Baljam opens at 14.00 tommorrow afternoon
(b) Cobain order Mac and Cheese yuk- Let us try to order Mac and Cheese
(c) Rekomended-recommended
(d) Isian dalam satu porsi-the filler in one portion
(e) Extra topping 
(f) sa uce Macaroni, cheese, cheddar dan potato chips

Registers (a-f) are several registers showing lexical items in the culinary field. Baljam itself is also a register which stands for balijamur. The community then used to say baljam. Register (c) the word rekommended is a loanword from English which is also more of a choice than the word recommended.

\subsubsection{SERVICES CATEGORY}

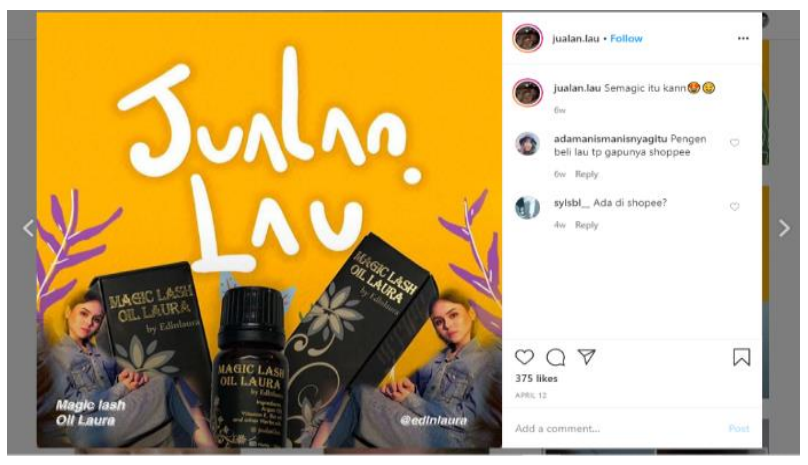

Picture 5. Services

The account of the above category shows the service category in terms of sales of Magic Lash Oil Laura which is displayed in bright orange shades. The registers found from the above account are
(a) Jualan Lau
- Selling Lau
(b) Semagic itukann-thatmagic....

\subsubsection{SHOPS CATEGORY}

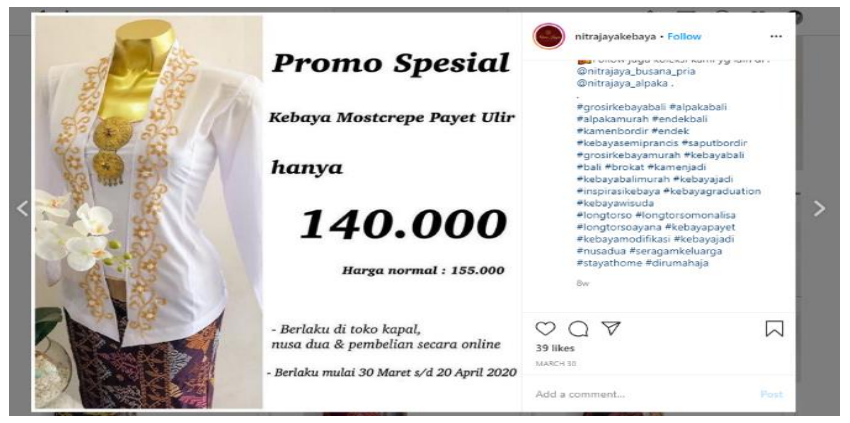

Picture 6. Shops

The account above is taken from the shop account of Nitra Jaya, with a picture of a white kebaya suit. The registers that can be found include the followings, that are shown in Indonesian phrase or sentences:

(a) Promo special - special promo

(b) Hanya..... - - just

(c) Harga normal-normal price

(d) Berlaku di toko kapal, nusa dua dan pembelian secara online - applicable in ka pal's shop, nusa dua and online purchasing

(e) Berlaku mulai 30 maretsd 20 april 2020 - valid from 30 march to 20 april 2020

Registers (a-e) are several registers related to sales marketing. This account is in the area of a shop that sells kebaya clothes. In order to attract consumer interest, register (a) is often used as a technique for making sales.

\subsection{The Function of Usage Specification Register in Social Media Instagram}

There are six types of register functions, namely instrumental, interaction, personal, problemsolving, imagination and information functions. The results of the data analysis above are as follows:

Data 1 shows that the language function used in the account is an information function. The information provided is an advertisement, namely about shampoo. The other register functions are not visible in this data. Likewise, data 2 and others also show information functions. The information 
function shown tends to be advertising products. Data 2 is about IndoMart advertisements, data 3 is about property sales, data 4 is information about culinary types, namely baljam, data 5 is included in the magic lash oil sales service category, and data 6 oriented towards selling kebaya clothes.

\section{CONCLUSION}

The results of data analysis showed that the usage specifications of registers found from the six categories of accounts that appear in social media Instagram were marketing, appeals and information registers. The marketing register was shown from the property category, and the services and store categories. Meanwhile, the appeal register was found in the mini-market / supermarket category. Information registers can be found in all data from existing categories. It can be found that the most 105 posts were from the service category of mini-markets / supermarkets and the data that showed the minimum frequency of appearance of posts was from the service category.

\section{REFERENCES}

Chaer, A. \& Agustina, L. (1995). Sosiolinguistik. Jakarta: Rineka Cipta.

Denscombe, M. (1998). The Good Research Guide. Philadelphia: Open University Press.

Djajasudarma, T. Fatimah. 1993. Metode Penelitian Linguistik: Ancangan, Metode Penelitian dan Kajian. Bandung: PT. Eresco.

Ferguson, C.A (1971). Language structure and language use. Stanford: Stanford University Press

Fishman, J. A. (1972). Sociolinguistics: A Brief Introduction. Massachussetts: Newburry House Publisher.

Halliday, M.A.K and Ruqaiya Hasan. (1985). Language, Context and Text: Aspects of Language in a Social Semiotic Perspective. Victoria: Deakin University Press

Hymes, D. (1964). Language in Culture and Society. New York: Happer and Row.

Hymes, D. Toward Ethnographies of Communication: The Analysis of Communicative Events in P. P. Giglioli, ed. (1971) Language and Social Context. Middlesex: Penguin Books, 1td.

Hudson, R.A. (1980). Sociolinguistics. Cambridge: Cambridge University Press.

Labov, W. The Study of Language in Its Social Context in P. P. Gigioli, ed (1972) Language and Social Context. Middlesex: Penguin Books Ltd.

Leech, Geofrey. (1993). Prinsip-prinsip Pragmatik (Terjemahan M. D. D. Oka) in Adeliani Noor. 2014. Lagu Menidurkan Anak pada Masyarakat Banjar: Kajian Bentuk, Makna, dan Fungsi. Jurnal AlBanjari Vol. 13, No. 2, Juli-Desember.

Lincoln, Y.S. \& Guba, E.G. (1985). Effective Evaluation. San Fransisco: yossey Bass Publisher.

Sudaryanto. (1993). Metode dan Aneka Teknik Analisis Bahasa. Yogyakarta: Duta Wacana University Press

Sumarsono. (2007). Sosiolinguistik. Yogyakarta: Pustaka Pelajar 
